\title{
Fructan production in Vernonia herbacea (Vell.) Rusby is related to adequate nitrogen supply and period of cultivation
}

\author{
GERALDO R. F. CUZZUOL ${ }^{1}$, MARIA ANGELA M. CARVALHO ${ }^{2}$ and LILIAN B. P. ZAIDAN ${ }^{2,3}$
}

(received: July 05, 2007; accepted: February 07, 2008)

\begin{abstract}
Fructan production in Vernonia herbacea (Vell.) Rusby is related to adequate nitrogen supply and period of cultivation). Previous studies showed that plants of Vernonia herbacea grown for one year under a limited nitrogen supply presented reduced growth and higher fructan content than plants treated with sufficient nitrogen supply. However, the total fructan production was similar in both plant groups due to the higher biomass of the underground reserve organ in nitrogensufficient (N-sufficient) plants. In the present study we aimed to evaluate if a stress growing condition under nitrogenlimited (N-limited) supply, following cultivation under $\mathrm{N}$-sufficient supply would have a positive effect on fructan production. Plants cultivated during one year under $\mathrm{N}$-sufficient supply $\left(10.7 \mathrm{mmol} \mathrm{L}{ }^{-1} \mathrm{~N}-\mathrm{NO}_{3}^{-}\right)$were separated in two groups. During the following six months, one group continued to receive the same treatment (control) while the other received an $\mathrm{N}$-limited supply $\left(1.3 \mathrm{mmol} \mathrm{L} \mathrm{N}^{-1} \mathrm{~N}-\mathrm{NO}_{3}^{-}\right)$. Growth, photosynthesis and soluble carbohydrates were measured at days $0,30,60,90$ and 180. At day 30, plants transferred to N-limited supply showed a significant increase in growth and a decrease in fructan concentration, as a response to the stressing condition. However, in the following period growth was reduced and fructan concentration was increased, confirming the inverse relationship between nitrogen concentration and fructan content. After 180 days, although the fructan concentration in $\mathrm{N}$-limited was significantly higher, with a fructan production of $6.0 \mathrm{~g}$ plant ${ }^{-1}$, the higher gain in rhizophore biomass after 18 months of cultivation in $\mathrm{N}$-sufficient solution led to a fructan production of $8.3 \mathrm{~g}$ plant $^{-1}$, thus surpassing the higher fructan concentration of $\mathrm{N}$-limited plants.
\end{abstract}

Key words - "cerrado" vegetation, inulin, nutritional stress, plant growth, underground reserve organ

RESUMO - (A produção de frutanos em Vernonia herbacea (Vell.) Rusby está relacionada com o suprimento adequado de nitrogênio e o tempo de cultivo). Estudos realizados anteriormente mostraram que plantas de Vernonia herbacea cultivadas durante um ano sob uma condição limitante de nitrogênio tiveram seu crescimento reduzido e apresentaram maiores teores de frutanos em comparação a plantas que receberam suprimento adequado de nitrogênio. Entretanto, a produção total de frutanos foi similar nos dois grupos de plantas devido à maior biomassa dos órgãos subterrâneos de reserva das plantas N-suficientes. O objetivo do presente estudo foi avaliar se o cultivo sob uma condição adequada de nitrogênio, que promove o crescimento das plantas, seguido de uma condição estressante de crescimento imposta por suprimento limitante de nitrogênio, promoveria a produção de frutanos. As plantas receberam durante um ano solução N-suficiente $\left(10,7 \mathrm{mmol} \mathrm{L}^{-1} \mathrm{~N}_{-} \mathrm{NO}_{3}^{-}\right)$. Nos seis meses subseqüentes, metade das plantas passou a receber solução $\mathrm{N}$-limitante $\left(1,3 \mathrm{mmol} \mathrm{L} \mathrm{L}^{-1} \mathrm{~N}-\mathrm{NO}_{3}^{-}\right)$, permanecendo as demais no tratamento $\mathrm{N}$-suficiente. $\mathrm{O}$ crescimento, a fotossíntese e os carboidratos solúveis foram analisados no dia da transferência (dia 0) e aos 30, 60, 90 e 180 dias. Aos 30 dias as plantas transferidas para N-limitado mostraram aumento significativo do crescimento e diminuição da concentração de frutanos, em resposta à condição nutricional estressante. No entanto, no período seguinte (60 dias) o crescimento foi reduzido e a concentração de frutanos aumentou em relação às plantas mantidas em N-suficiente, confirmando a relação inversa entre suprimento de nitrogênio e conteúdo de frutanos. Após 180 dias, embora a concentração de frutanos em N-limitado tenha sido significativamente mais elevada, com uma produção de frutanos de 6,0 $\mathrm{g} \mathrm{planta}^{-1}$, o maior ganho de biomassa de rizóforos observado nas plantas mantidas sob N-suficiente durante 18 meses, levou a uma produção de frutanos de $8,3 \mathrm{~g} \mathrm{planta}^{-1}$, compensando assim a menor concentração de frutanos observada nessas plantas.

Palavras-chave - estresse nutricional, cerrado, crescimento vegetal, inulina, órgão subterrâneo de reserva

\section{Introduction}

A biological stress is defined as any change in environmental condition that might reduce or adversely

1. Universidade Federal do Espírito Santo, Departamento de Ciências Biológicas, 29060-900 Vitória, ES, Brasil

2. Instituto de Botânica, Seção de Fisiologia e Bioquímica de Plantas, Caixa Postal 3005, 01061-970 São Paulo, SP, Brasil

3. Corresponding author: lilianzaidan@uol.com.br change a plant growth or development (Levitt 1980). Any change in the environment that results in plant response that is less than the optimum might be considered stressful (Salisbury \& Ross 1991). In plants, water and nutritional deficiency, high salinity and extreme temperatures are some of the most studied stress factors (Lambers et al. 1998).

Nutritional deficit, especially nitrogen, triggers a number of responses, that are expressed by changes in 
the shoot:root ratio and in the metabolism of leaves and reserve organs. The reduction of cell division and cell expansion, leaf production and photosynthesis are evident effects in response to nitrogen deficiency (Chapin et al. 1988). In some species of Asteraceae and Poaceae, for example, nitrogen restriction increased the contents of fructan-type carbohydrates (Wang \& Tilberg 1996, Améziane et al. 1997, Van den Ende et al. 1999).

Plants use different mechanisms in order to compensate for the negative effects of stress. These mechanisms operate in different time scales, depending on the type of stress and on the affected physiological process (Lambers et al. 1998). When a stress factor is first experienced, an alarm reaction occurs, in which the function of interest deviates markedly from the norm. Then comes the resistance stage or restitution phase, in which the organism adapts to the stress factor and the function often returns towards its normal state, not always completely achieved. If the stress factor increases or continues for a long time, the stage of exhaustion may be reached, in which the function may again strongly deviates from the average, leading eventually to death (Larcher 2003).

These stages are well documented for crops but information about the adaptive strategies of plants native to the cerrado in relation to nutritional deficiency is scarce (Haridasan et al. 1997). It is suggested that the low availability of nutrients in the cerrado soil affects carbon partitioning and leads to specific morphological characteristics such as scleromorphism. Paulilo \& Felippe (1995) and Sassaki \& Felippe (1998) alleged that the cerrado vegetation accumulates more carbohydrates than proteins due to the low nutrient availability in the soil.

The nutrient availability in the cerrado is even lower during winter, when precipitation and temperature decrease. This factor contributes to the low growth rates, the biomass allocation to underground organs (Felippe \& Dale 1990, Isejima \& Figueiredo-Ribeiro 1991, Carvalho et al. 1997), and the low photosynthetic capacity (Prado \& Moraes 1996). Another common feature in the cerrado is the occurrence of underground reserve organs in herbaceous species of Asteraceae presenting fructans, as reported by Figueiredo-Ribeiro et al. (1992) and Tertuliano \& Figueiredo-Ribeiro (1993).Vernonia herbacea (Vell.) Rusby is one of these species that accumulates fructans of the inulin type in the underground reserve organs, the rhizophores (Carvalho \& Dietrich 1993). This species has been considered a potential source for inulin production, although it lacks a history as a crop. Thus, studies focusing on mineral nutrition are being conducted in order to increase inulin production by these plants.

Previous results with $V$. herbacea showed that the ideal nitrogen concentration for plant growth is $10.7 \mathrm{mmol} \mathrm{L}^{-1} \mathrm{~N}-\mathrm{NO}_{3}^{-}$and that $1.3 \mathrm{mmol} \mathrm{L}^{-1} \mathrm{~N}-\mathrm{NO}_{3}^{-}$ provides a limiting growth condition (Cuzzuol et al. 2005a). Therefore, the use of this N-limited concentration satisfies the criteria established for the study of a specific stress factor. A later study by Cuzzuol et al. (2005b) reported that plants growing during one year under $\mathrm{N}$-limited supply presented higher fructan contents in spite of a final reduced growth and lower rhizophore biomass, when compared to $\mathrm{N}$-sufficient plants. Nevertheless, fructan production was very similar in both $\mathrm{N}$-treatments at the end of the experimental period, due to the lower rhizophore biomass in the N-limited plants. In the present study, we aimed to verify if plants cultivated for one year under an ideal nitrogen supply for plant growth would attain a further higher fructan production after transference to a limiting nitrogen growth condition.

\section{Material and methods}

Plant material, growing conditions and sampling - Plants of Vernonia herbacea (Vell.) Rusby (Herbarium number: SP169567) were obtained and cultivated as described by Cuzzuol et al. (2005b). Plants received, weekly, $100 \mathrm{~mL}$ of a specific nutrient solution containing $10.7 \mathrm{mmol} \mathrm{L}^{-1} \mathrm{~N}_{-} \mathrm{NO}_{3}^{-}$, elaborated to supply adequate nitrogen required by $V$. herbacea as previously determined by Cuzzuol et al. (2005a). After twelve months of growth, half of the plants continued to receive the same solution (control plants) while the other half received an $\mathrm{N}$-limited nutrient solution

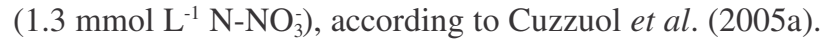
Otherwise plants were regularly irrigated with distilled water. The plants were maintained in a glasshouse under natural photoperiod and temperature (mean minimum and maximum temperatures of $18^{\circ} \mathrm{C}$ and $29^{\circ} \mathrm{C}$ ). The differential nutritional treatments were applied from December 2001 to June 2002, a period that includes the vegetative and early dormancy in $V$. herbacea (Carvalho \& Dietrich 1993). The experiment was conducted at the Instituto de Botânica (2338'25” S, 46³7'19” W), São Paulo, Brazil. Six plants (each plant representing one replicate) were collected from each treatment at days $0,30,60,90$ and 180, counting from the beginning of the N-limited treatment, for growth evaluation, photosynthesis and carbohydrate analyses.

Growth analysis - Growth measurements included plant height, shoot number, dry masses of the aerial and underground organs, leaf number and leaf area. The dry mass was determined after drying the tissues at $60{ }^{\circ} \mathrm{C}$, to constant weight. Leaf area was calculated using the Leaf 
Area \& Analysis software (Skye Instruments Ltd.). Specific leaf mass (SLM) was calculated by the ratio of leaf mass and leaf area. The relative growth rate (RGR) was calculated according to Hunt (1978).

Photosynthesis - Photosynthesis, conductance, transpiration and internal $\mathrm{CO}_{2}$ concentration were measured in the first completely expanded leaf of each plant between $9 \mathrm{~h}$ and $11 \mathrm{~h}$, corresponding to maximum photosynthetic activity in this species, according to preliminary evaluation. The analyses were accomplished in a closed system, with a portable infrared gas analyzer (IRGA), LI-6400 model (LI-COR, Inc.) equipped with a light chamber (LI-6400-02B), at $500 \mu \mathrm{mol} \mathrm{m} \mathrm{m}^{-2} \mathrm{~s}^{-1}$ radiation, leaf temperature of $25{ }^{\circ} \mathrm{C}$ and at natural $\mathrm{CO}_{2}$ concentration of the glasshouse.

Extraction and analyses of soluble carbohydrates - Samples of fresh rhizophores ( $2 \mathrm{~g}$ ) and leaves ( $1 \mathrm{~g}$ ) were submitted to oligo- and polysaccharide extraction as described by Carvalho et al. (1998). For standardization purposes, samples were taken from the medium portion of the rhizophores and from apical leaves completely expanded. Free and combined fructose ware measured in the rhizophore crude extracts by a ketose-specific modification of the anthrone reaction (Jermyn 1956). Crude extracts from rhizophores and leaves were submitted to ethanol precipitation; fructo-oligosaccharide and fructo-polysaccharide fractions were separated by centrifugation (Asega \& Carvalho 2004). For the quantification of glucose, fructose and sucrose, samples from the fructo-oligosaccharide fraction were de-ionized (Carvalho \& Dietrich 1993) and analyzed by high performance anion exchange chromatography with a pulse amperometric detector (HPAEC/PAD) using external standards on a 4 x $250 \mathrm{~mm}$ CarboPac PA-1 column in a Dionex System Mod. DX-300. The gradient was established by mixing eluant $\mathrm{A}(150 \mathrm{mM} \mathrm{NaOH})$ and eluant $\mathrm{B}$ (500 mM sodium acetate in $150 \mathrm{mM} \mathrm{NaOH}$ ) as follows: 0-2 $\mathrm{min}, 25 \mathrm{mM}$; 2-8 $\mathrm{min}, 25-150 \mathrm{mM}$; 8-28 min, 150-500 mM; 28-30 min, $25 \mathrm{mM}$ with a flow rate of $1.0 \mathrm{~mL} \mathrm{~min}{ }^{-1}$. The applied potentials for E1 $(480 \mathrm{~ms})$, E2 $(120 \mathrm{~ms})$ and E3 $(60 \mathrm{~ms})$ were $+0.05,+0.60$ and $-0.60 \mathrm{~V}$, respectively.

Statistical analysis - Data were analyzed by one way ANOVA and the means were compared by Tukey $(P<0.05$ and $P<0.01$ ).

\section{Results}

In both treatments with $\mathrm{NO}_{3}^{-}$, the plants grew in height until day 90, coinciding with the end of the summer (March). From day 90 on, growth was arrested and plants started to senesce; on day 180, at the stage of early dormancy, they presented no shoots (figure 1). The nitrogen deficient plants presented a slight increase in shoot number soon after the start of the treatment (figure 1), as well as in leaf number and in total leaf
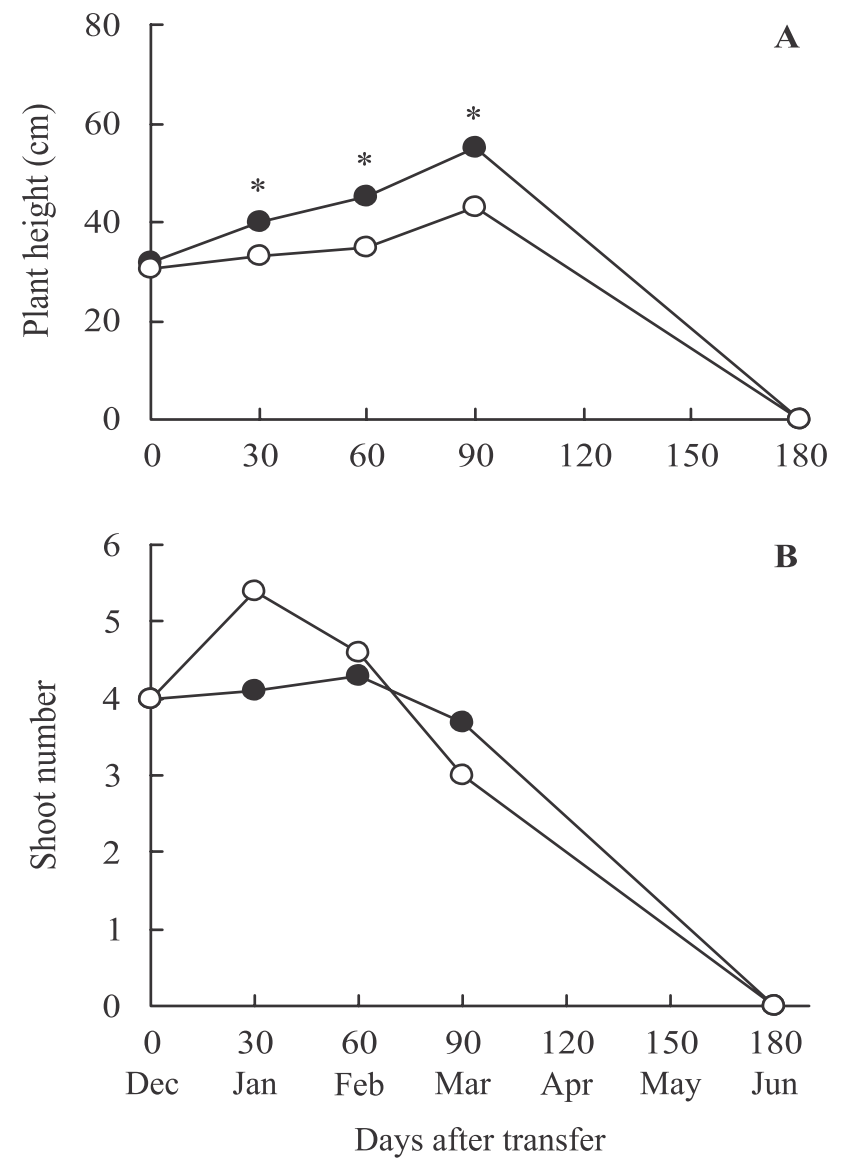

Figure 1. (A) Plant height $(\mathrm{cm})$ and (B) shoot number of plants of $V$. herbacea transferred from a N-sufficient ( $\bullet$, control) to a N-limited (o) solution. $* P<0.05(n=6)$.

area (figure 2). However, subsequent evaluations showed that $\mathrm{N}$-limited plants presented a decrease in all these measurements and maintained values below those of the control plants until day 180 . The specific leaf mass (figure 2) of approximately $90 \mathrm{mg} . \mathrm{cm}^{-2}$ was maintained during the growth period, with no significant differences between the two nutritional conditions. The variation observed on growth measurements reflected on the dry mass of the aerial organs (figure 3 ), which showed a higher increment at day 30 and a subsequent decline, with values significantly lower than the control on days 60 and 90. As for the rizophores, no increment in dry mass was observed throughout the experimental period in plants transferred to the restricted nitrogen treatment (figure 3) whereas control plants presented significant dry mass increases from day 60 to day 180, reaching values twice as high as those found in the $\mathrm{N}$-limited plants.

Photosynthesis rate, conductance, transpiration and internal $\mathrm{CO}_{2}$ concentration decreased on day 30 but an 

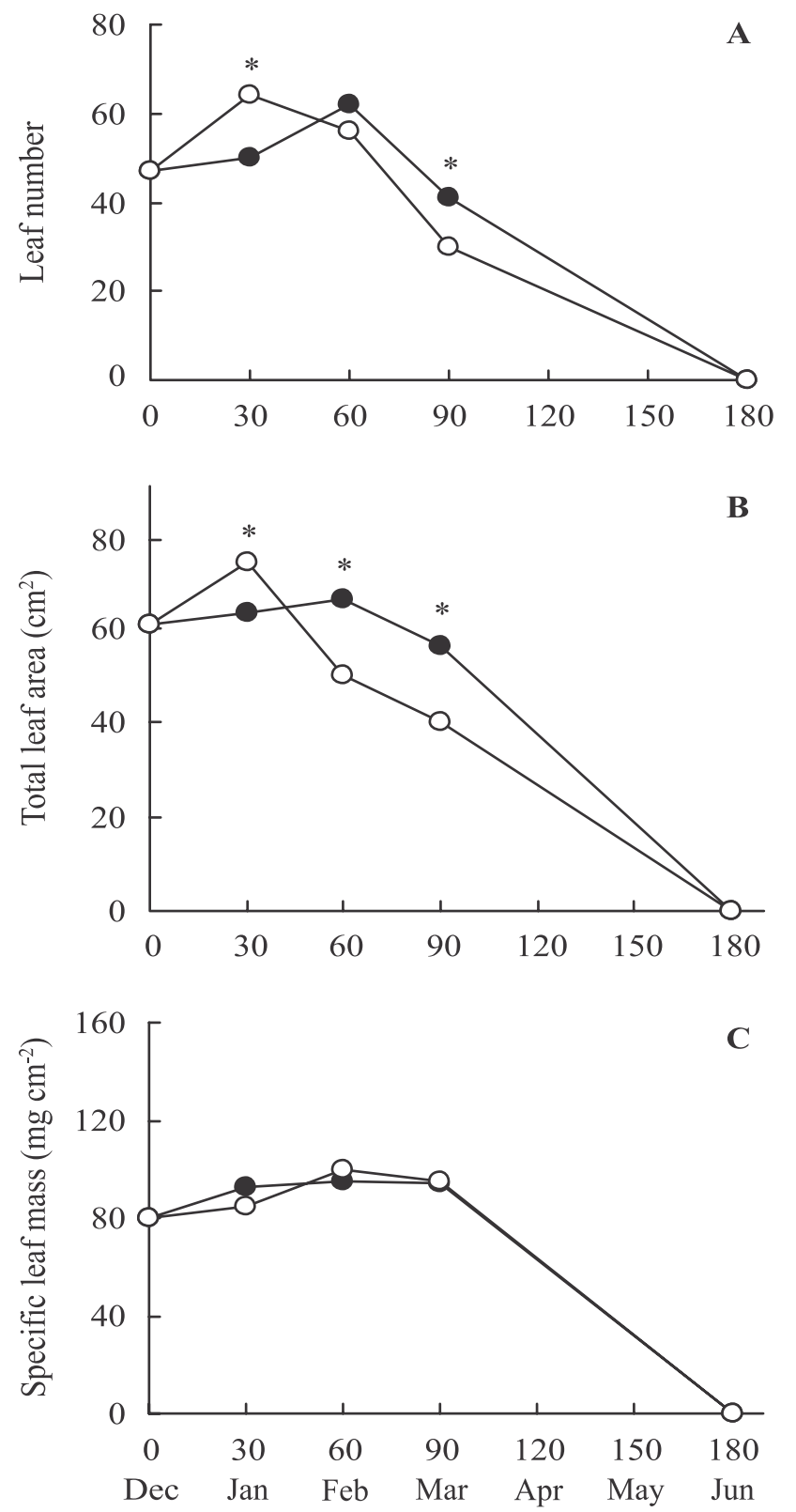

Days after transfer

Figure 2. (A) Leaf number, (B) total leaf area $\left(\mathrm{cm}^{2}\right)$ and (C) specific leaf mass $\left(\mathrm{mg} \mathrm{cm}^{-2}\right)$ of plants of $V$. herbacea transferred from a $\mathrm{N}$-sufficient ( $\bullet$, control) to a $\mathrm{N}$-limited (o) solution. $* P<0.05(n=6)$.

increase was observed in the following 30 days in both treatments. Significantly higher values were found in the control plants at this sampling day, except for the internal $\mathrm{CO}_{2}$ concentration which presented consistent lower values in the control plants. After 60 days, a reduction in photosynthesis and in the related parameters was detected (figure 4). Positive correlations between photosynthesis and conductance $\left(r^{2}=0.657^{*}\right)$ and
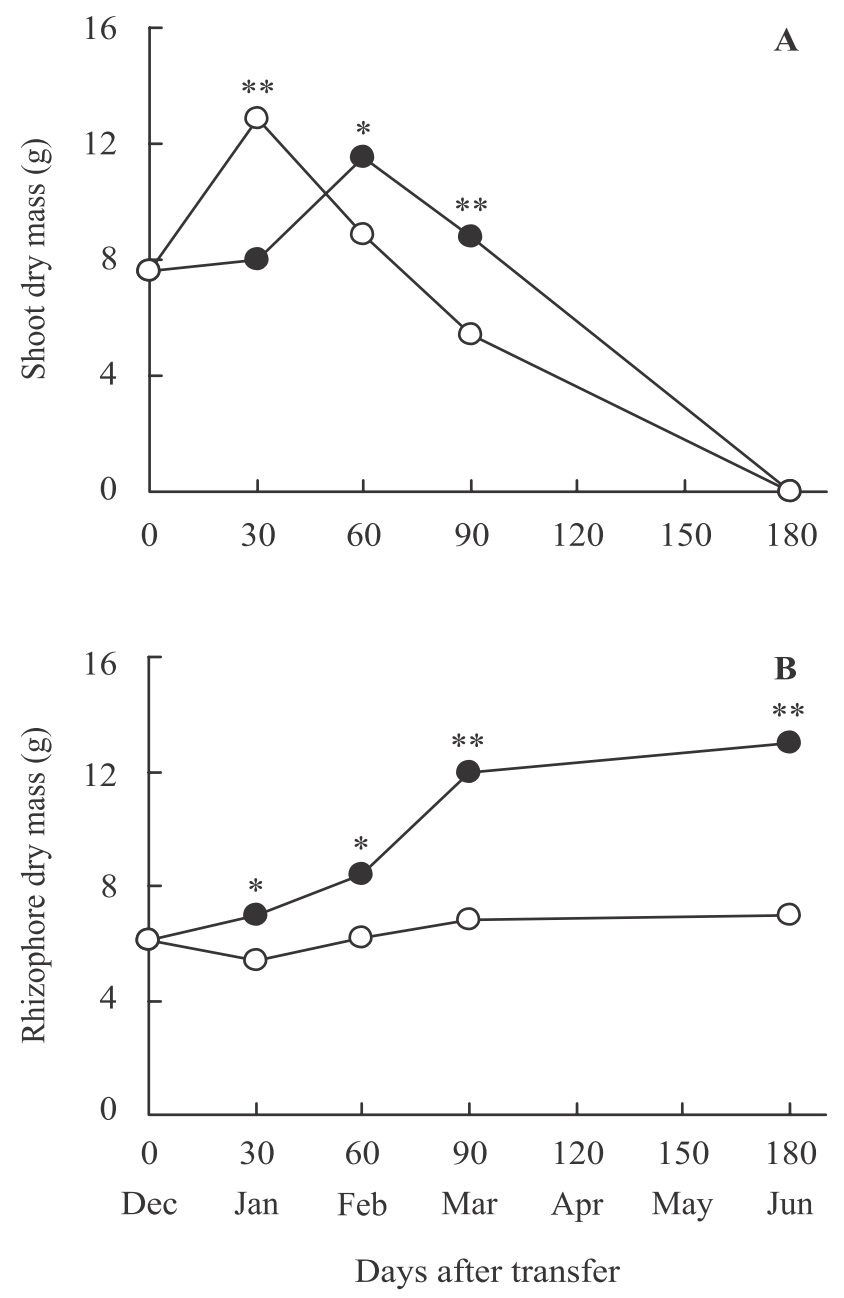

Figure 3. (A) Shoot dry mass (g) and (B) rhizophore dry mass $(\mathrm{g})$ of plants of $V$. herbacea transferred from a $\mathrm{N}$-sufficient ( $\bullet$, control) to a $\mathrm{N}$-limited (o) solution. $* P<0.05$, ** $P<0.01(n=6)$.

between photosynthesis and transpiration $\left(r^{2}=0.843^{*}\right)$ were found.

The total fructose concentration in the rhizophores of $\mathrm{N}$-limited plants decreased $30 \%$ in the first 30 days after transferring to $\mathrm{N}$-limited solution (figure 5), increased after day 60 and reached values significantly higher at day 180 (end of autumn) corresponding to about $80 \%$ of the rhizophore dry mass. In control plants, fructose concentration corresponded to about $60 \%$ of the dry mass throughout the experimental period with a slight increase on day 180. However, in terms of fructan production, control plants presented significant higher yields throughout the experimental period (figure 5), reaching $8.3 \mathrm{~g} \mathrm{plant}^{-1}$, while plants transferred to $\mathrm{N}$-limited condition reached only $6.0 \mathrm{~g}$ plant $^{-1}$, consistent with the lower rhizophore dry mass presented by these plants (figure 3 ). 

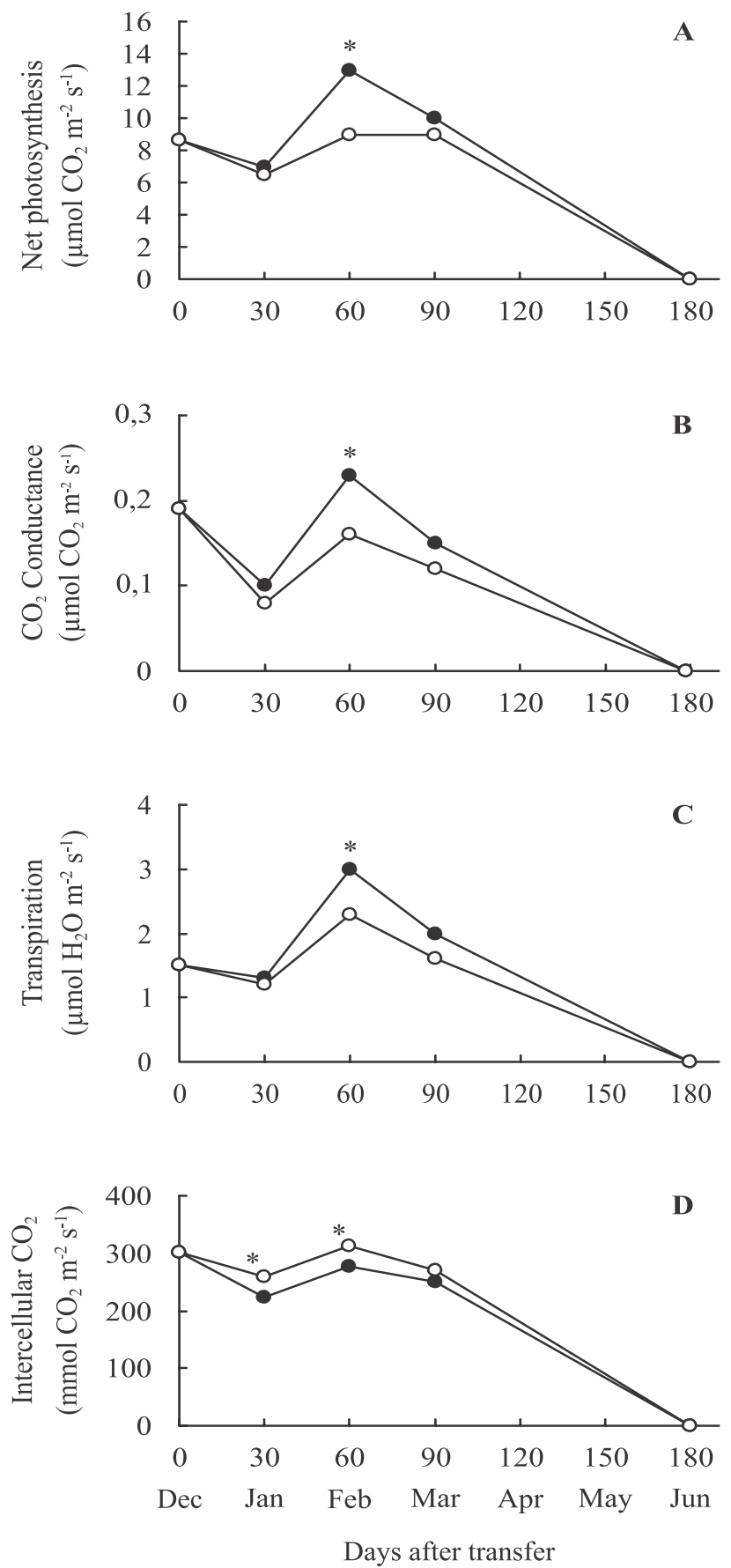

Figure 4. (A) Net photosynthesis ( $\mu \mathrm{mol} \mathrm{CO}_{2} \mathrm{~m}^{-2} \mathrm{~s}^{-1}$ ), (B) $\mathrm{CO}_{2}$ conductance $\left(\mu \mathrm{mol} \mathrm{CO} \mathrm{C}^{-2} \mathrm{~s}^{-1}\right),(\mathrm{C})$ transpiration $(\mu \mathrm{mol}$ $\left.\mathrm{H}_{2} \mathrm{O} \mathrm{m}^{-2} \mathrm{~s}^{-1}\right)$ and (D) intercellular $\mathrm{CO}_{2}\left(\mathrm{mmol} \mathrm{CO} \mathrm{Cm}^{-2} \mathrm{~s}^{-1}\right)$ in plants of $V$. herbacea transferred from a N-sufficient ( $\bullet$, control) to a N-limited (o) solution. * $P<0.05(n=6)$.

Glucose, fructose and sucrose concentration in leaves was generally lower than in rhizophores and no differences were found for the two treatments. In both nutritional conditions, these soluble carbohydrates
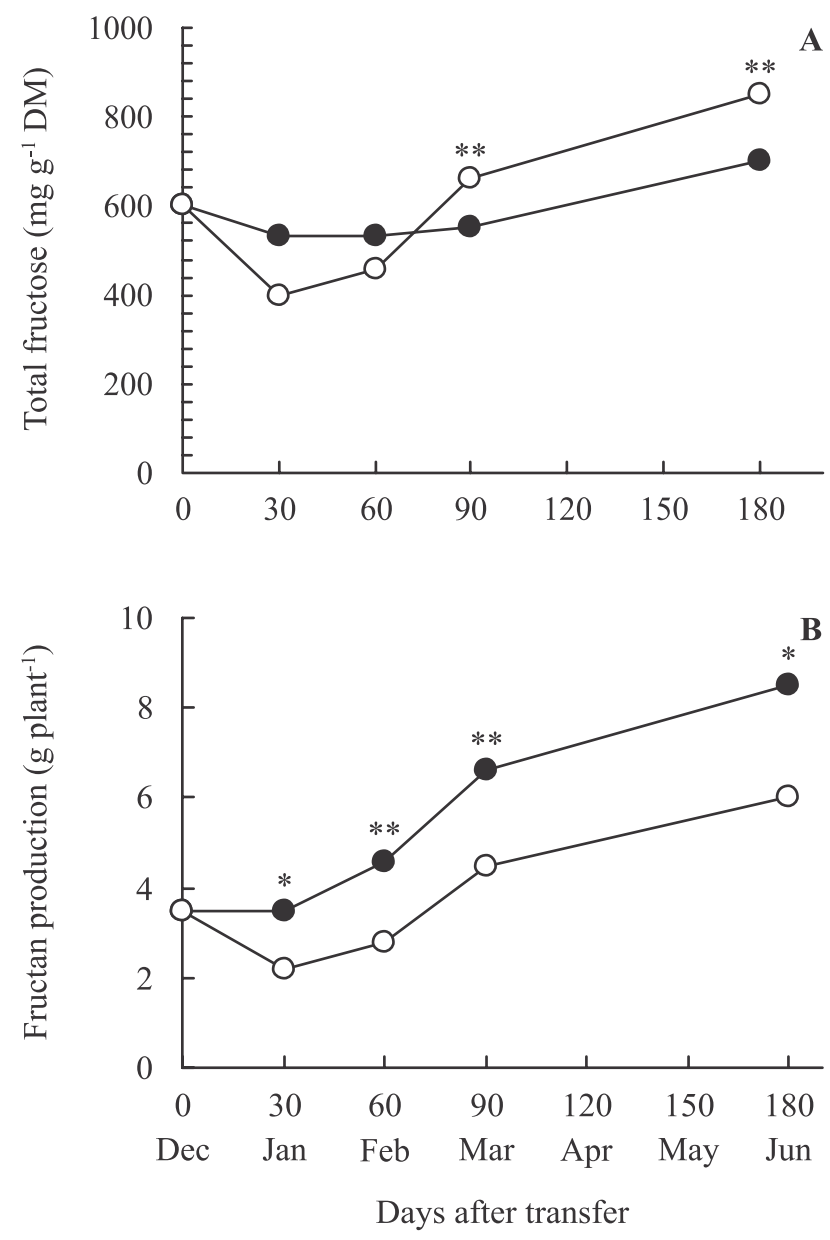

Figure 5. (A) Total fructose ( $\left.\mathrm{mg} \mathrm{g}^{-1} \mathrm{DM}\right)$ and (B) fructan production $\left(\mathrm{g} \mathrm{plant}^{-1}\right)$ of plants of $V$. herbacea transferred from a N-sufficient ( $\bullet$, control) to a $\mathrm{N}$-limited (o) solution. $* P<0.05, * * P<0.01(n=6)$.

presented an increase at day 30 , followed by a decrease in the subsequent days of observation (figure 6).

In the rhizophores at day 30, an increase in the concentration of glucose and fructose was also observed in plants of both treatments (figure 6). The concentration of glucose, fructose and sucrose was increased in plants treated with the N-limited solution. In these plants glucose was higher between days 90 and 180, fructose was markedly higher at day 30 and sucrose was higher throughout the experimental period. However, plants of both treatments showed a similar pattern of sucrose concentration, with a gradual decrease until day 90 .

\section{Discussion}

The increase in the biomass of aerial organs in the first 30 days of treatment in plants transferred to limited 

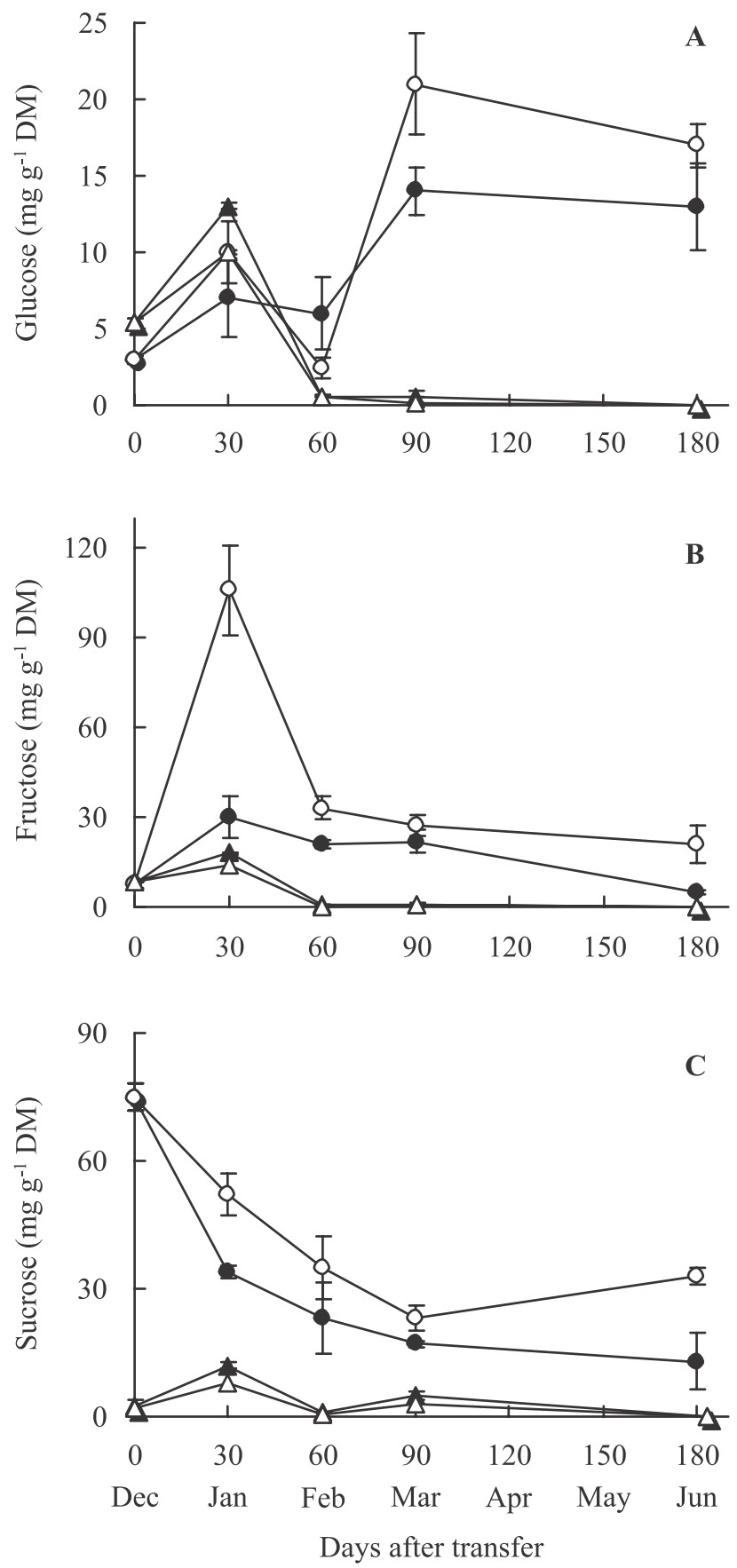

Figure 6. Contents of (A) glucose ( $\left.\mathrm{mg} \mathrm{g}^{-1} \mathrm{DM}\right),(\mathrm{B})$ fructose $\left(\mathrm{mg} \mathrm{g}^{-1} \mathrm{DM}\right)$ and $(\mathrm{C})$ sucrose $\left(\mathrm{mg} \mathrm{g}^{-1} \mathrm{DM}\right)$ in rhizophores $(\bullet \circ)$ and leaves $(\Delta \Delta)$ of plants of $V$. herbacea transferred from a $\mathrm{N}$-sufficient (closed symbols, control) to a $\mathrm{N}$-limited (open symbols) solution. Bars represent standard error $(n=3)$.

nitrogen supply was due mainly to the formation of new leaves (figures 1, 2 and 3). In the same period these plants presented also higher RGR values $\left(11.8 \mathrm{mg} \mathrm{g}^{-1} \mathrm{~d}^{-1}\right.$ in $\mathrm{N}$-limited and $2.3 \mathrm{mg} \mathrm{g}^{-1} \mathrm{~d}^{-1}$ in $\mathrm{N}$-sufficient plants).
Anticipation of growth is a common feature of plants under nutritional deficiency (Lichtenthaler 1996, Lambers et al. 1998, Larcher 2003). This response is expected, since nutritional stress leads first to an alarm stage when growth is adjusted as a strategy to guarantee plant survival and to compensate for possible damages caused by the stressing factor. Early flowering can also occur under stress conditions such as water deficit and nutritional deficiency (Marschner 1995, Larcher 2003), although flowering was not observed in plants of $V$. herbacea during the experimental period. However, it should be pointed out that vegetative reproduction through rhizophores predominates in this species as sexual reproduction is hampered by a low germinability of the achenes (Carvalho et al. 1997, Sassaki et al. 1999).

A long term study on growth of $V$. herbacea under both sufficient and limited nitrogen supply (Cuzzuol et al. 2005b) showed that these plants present a low RGR potential, similar to plants native to poor soils (Lambers \& Poorter 1992, Paulilo \& Felippe 1995, Sassaki \& Felippe 1998). According to their response to nutrient levels, the authors characterized $V$. herbacea as a Type I species, following the classification of Chapin (1980, 1988) for wild species. Chapin (1988) also reported that slow growth species under high fertility accumulate nutrients in the vacuoles, to be used when the nutritional conditions are limited (luxury consumption). If this was the case in $V$. herbacea, a reduction in the specific leaf mass in plants submitted to nitrogen deficiency should have been detected. However, SLM of both N-limited and control plants were very similar, suggesting that nitrogen had a small contribution for the leaf cell mass.

In plants submitted to N-limitation the fast growth of the aerial organs detected at day 30 , probably during the resistance stage, occurred concomitant to a $13 \%$ decrease in rhizophore biomass and a 33\% decrease in fructan concentration (figure 5).

Carbohydrate mobilization to attend aerial growth is well described in the literature (e.g. Chapin et al. 1990). In V. herbacea, fructan mobilization in the sprouting and flowering phases (Carvalho \& Dietrich 1993 ) is concurrent with an increase in the activity of fructan exohydrolases (FEH) (Asega \& Carvalho 2004).

Although the activity of FEH was not determined in the present study, the marked increase in free fructose observed in N-limited plants at day 30 (the resistance stage) resulted possibly from fructan mobilization by this enzyme, since it coincided with a decrease in fructan contents (figures 5,6). The energy rich compounds yielded were used to supply the more intense aerial 
growth in this period verified in $\mathrm{N}$-limited plants (figures 1-3).

The high levels of glucose observed between 90 and 180 days in N-limited plants correlates with the increase in fructan concentration detected during this period, as it is released from sucrose by the action of sucrose: sucrose fructosyltransferase (SST) during fructan synthesis. These variations were also detected in control plants, although less markedly, a result consistent with the lower fructan concentration usually detected when aerial growth is favored as shown by Cuzzuol et al. (2003).

It is reported that when sucrose concentration is in excess, fructan synthesis in reserve organs is enhanced (Pollock \& Cairns 1991). This seems to be the case in N-limited plants at day 180 , when a high sucrose concentration in the rhizophores, in addition to the higher glucose levels (figure 6), coincided with the higher fructan concentration (figure 5) in these plants.

The high values of fructan contents observed in $\mathrm{N}$-limited plants (figure 4) are consistent with other studies that showed an inverse relationship between fructan content and nitrogen concentration (Améziane et al. 1997, Wang \& Tilberg 1996, McGrath et al. 1997, Van den Ende et al. 1999). However, the fructan yield after 180 days was lower in plants transferred to N-limited solution due to their lower rhizophore biomass (figure 3 ), as previously reported for plants of $V$. herbacea cultivated exclusively under $\mathrm{N}$-sufficient or N-limited conditions during one year (Cuzzuol et al. 2005b).

More than $75 \%$ of the leaf nitrogen is located in the chloroplasts (Evans 1989), as part of enzymes, pigments and other compounds involved in photosynthesis (Warren et al. 2000, Broadley et al. 2001). The stress caused by the lower nitrogen supply can explain the lower photosynthetic efficiency verified in N-limited plants, mainly at day 60 (figure 4).

Although the relationship between photosynthetic capacity and leaf nitrogen concentration is thoroughly documented (Evans 1989, Evans \& Seemann 1989, Alt et al. 2000), a correlation between photosynthesis and leaf protein concentration (data not shown) in $V$. herbacea was not observed $\left(r^{2}=0.005\right)$. According to Chapin et al. (1988) and Broadley et al. (2001), the negative effect of nitrogen restriction on photosynthesis is more related to stomatal resistance than to the kinetics of the enzymes involved in carbon fixation. However, the higher internal $\mathrm{CO}_{2}$ concentration found in $V$. herbacea under N-limited treatment (figure 4) suggests a low carboxylation activity (Larcher 2003, Broadley et al. 2001).
A hypothesis on the role of nitrogen on photosynthesis was presented by Chapin et al. (1988). According to these authors, nitrogen restriction promotes an increase in the content of abscisic acid (ABA), causing stomatal closure and a reduction in photosynthesis. ABA also promotes protein hydrolysis (Chapin et al. 1990) thus affecting the mobilization of organic nitrogen. The lowest values of photosynthetic measurements in plants of $V$. herbacea under nitrogen limitation could be a result of a low stomatal conductance and protein contents, affecting Rubisco activity and electron transport (Evans 1983).

The transference of plants to an N-limited condition after one year growing under $\mathrm{N}$-sufficient solution led initially to a decrease in fructan concentration and a concomitant increase in aerial growth, in accordance to the growth responses expected during the resistance phase in plants under stress conditions. So, the results obtained so far allow us to conclude that the responses of $V$. herbacea to low nitrogen supply can be regarded as an adaptive strategy to a stressing environment. After this resistance phase and up to the final observation, limiting nitrogen supply, a condition that caused growth reduction, increased total fructan concentration. Nevertheless, the gain in rhizophore biomass at the end of 18 months of cultivation under an adequate nitrogen supply was higher $\left(8.3 \mathrm{~g} \mathrm{plant}^{-1}\right)$, and compensated for the lower fructan concentration, surpassing the final yield obtained in N-limited plants (6.0 g plant $\left.{ }^{-1}\right)$.

Acknowledgements - This research was funded by Fundação de Amparo à Pesquisa do Estado de São Paulo (FAPESP, Proc. 98/05124-8 and 2005/04139-7) and Conselho Nacional de Desenvolvimento Científico e Tecnológico (CNPq). Lílian B. P. Zaidan and Maria Angela M. Carvalho are research fellows of CNPq; Geraldo R. F. Cuzzuol thanks Coordenação de Aperfeiçoamento de Pessoal do Ensino Superior (CAPES) for the PhD fellowship.

\section{References}

ALT, C., STUTZEL, H. \& KAGE, H. 2000. Optimal nitrogen content and photosynthesis in cauliflower (Brassica oleracea L. botrytis). Scaling up from a leaf to the whole plant. Annals of Botany 85:779-787.

AMÉZIANE, R., RICHARD-MOLARD, C., DELÉENS, E., MOROT-GAUDRY, J-F. \& LIMAMI, A.M. 1997. Nitrate $\left({ }^{15} \mathrm{NO}_{3}\right)$ limitation affects nitrogen partitioning between metabolic and storage sinks and nitrogen reserve accumulation in chicory (Cichorium intybus L.). Planta 202:303-312. 
ASEGA, A.F. \& CARVALHO, M.A.M. 2004. Fructan metabolising enzymes in rhizophores of Vernonia herbacea upon excision of aerial organs. Plant Physiology and Biochemistry 42:313-319.

BROADLEY, M.R., ESCOBAR-GUTIÉRREZ, A.J., BURNS, A. \& BURNS, I.G. 2001. Nitrogen-limited growth of lettuce is associated with lower stomatal conductance. New Phytologist 152:97-106.

CARVALHO, M.A.M. \& DIETRICH, S.M.C. 1993. Variation in fructan content in the underground organs of Vernonia herbacea (Vell.) Rusby at different phenological phases. New Phytologist 123:735-740.

CARVALHO, M.A.M., PINTO, M.M. \& FIGUEIREDORIBEIRO, R.C.L. 1998. Inulin production by Vernonia herbacea as influenced by mineral fertilization and time of harvest. Revista Brasileira de Botânica 21:275-280.

CARVALHO, M.A.M., ZAIDAN, L.B.P. \& DIETRICH, S.M.C. 1997. Growth and fructan content of plants of Vernonia herbacea (Asteraceae) regenerated from rhizophores. New Phytologist 136:153-161.

CHAPIN III, F.S. 1980. The mineral nutrition of wild plants. Annual Review of Ecology and Systematics 11:233-260.

CHAPIN III, F.S. 1988. Ecological aspects of plant mineral nutrition. In Advances in Plant Nutrition (B. Tinker \& A. Läuchli, eds.). Praeger, New York, v.3, p.161-191.

CHAPIN III, F.S., SCHULZE, E.D. \& MOONEY, H.A. 1990. The ecology and economics of storage in plants. Annual Review of Ecology 21:423-447.

CHAPIN III, F.S., WALTER, C.H.S. \& CLARKSON, D.T. 1988. Growth response of barley and tomato to nitrogen stress and its control by abscisic acid, water relations and photosynthesis. Planta 173:352-366.

CUZZUOL, G.R.F., CARVALHO, M.A.M., BARBEDO, C.J. \& ZAIDAN, L.B.P. 2003. Crescimento e conteúdo de frutanos em plantas de Vernonia herbacea (Vell.) Rusby submetidas à adubação nitrogenada. Revista Brasileira de Botânica 26:81-91.

CUZZUOL, G.R.F., CARVALHO, M.A.M., ZAIDAN, L.B. P. \& FURLANI, P.R. 2005a. Soluções nutritivas para o cultivo e a produção de frutanos em plantas de Vernonia herbacea. Pesquisa Agropecuária Brasileira 40:911-917.

CUZZUOL, G.R.F., CARVALHO, M.A.M. \& ZAIDAN, L.B.P. 2005b. Growth, photosynthate partitioning and fructan accumulation in plants of Vernonia herbacea (Vell.) Rusby under two nitrogen levels. Brazilian Journal of Plant Physiology 17:401-410.

EVANS, J.R. 1983. Nitrogen and photosynthesis in the flag leaf of wheat (Triticum aestivum L.). Plant Physiology 72:297-302.

EVANS, J.R. 1989. Partitioning of nitrogen between and within leaves grown under different irradiances. Australian Journal of Plant Physiology 16:533-548.

EVANS, J.R. \& SEEMANN, J.R. 1989. The allocation of protein nitrogen in the photosynthetic apparatus: costs, consequences, and control. In Photosynthesis (W.R. Briggs, ed.). Alan R Liss Inc., New York, p.183-205.
FELIPPE, G.M. \& DALE, J.E. 1990. The effects of phosphate supply on growth of plants from the Brazilian Cerrado: experiments with seedlings of the annual weed, Bidens gardneri Baker (Compositeae) and the tree, Qualea grandiflora (Mart.) (Vochysiaceae). Oecologia 82: 81-86.

FIGUEIREDO-RIBEIRO, R.C.L., ISEJIMA, E.M., DIASTAGLIACOZZO, G.M., CARVALHO, M.A.M. \& DIETRICH, S.M.C. 1992. The physiological significance of fructan accumulation in Asteraceae from the cerrado. Ciência e Cultura 43:443-446.

HARIDASAN, M., PINHEIRO, A.A.M.C. \& TORRES, F.R. R. 1997. Resposta de algumas espécies do estrato rasteiro de um cerrado à calagem e à adubação. In Contribuição ao conhecimento ecológico do cerrado (L.L. Leite \& C.H. Saito, eds.). Embrapa, Brasília, p.87-91.

HUNT, R. 1978. Plant growth analysis. Edward Arnold, London.

ISEJIMA, E.M. \& FIGUEIREDO-RIBEIRO, R.C.L. 1991. Partição de matéria seca durante o desenvolvimento de Viguiera discolor. Revista Brasileira de Botânica 14:107-114.

JERMYN, M.A. 1956. A new method for the determination of ketohexoses in presence of aldohexoses. Nature 177:38-39.

LAMBERS, J. \& POORTER, H. 1992. Inherent variation in growth rate between higher plants: a search for physiological causes and ecological consequences. Advance in Ecology Research 23:187-261.

LAMBERS, J., CHAPIN III, F.S. \& PONS, T.L. 1998. Plant physiological ecology. Springer-Verlag, New York.

LARCHER, W. 2003. Physiological plant ecology. Springer, Berlin.

LEVITT, J. 1980. Responses of Plants to Environmental Stresses. Academic Press, New York.

LICHTENTHALER, H.K. 1996. Vegetation stress: an introduction to the stress concept in plants. Journal of Plant Physiology 148:4-14.

MARSCHNER, H. 1995. Mineral Nutrition of Higher Plants. Academic Press, Orlando.

MCGRATH, V.B., BLAKENEY, A.B. \& BATTEN, G.D. 1997. Fructan to nitrogen ratio as an indicator of nutrient stress in wheat crops. New Phytologist 136: 145-152.

PAULILO, M.T.S. \& FELIPPE, G.M. 1995. Respostas de plântulas de Qualea grandiflora, uma espécie arbórea de cerrado, à adição de nutrientes minerais. Revista Brasileira de Botânica 18:109-112.

POLLOCK, C.J. \& CAIRNS, A.J. 1991. Fructan metabolism in grasses and cereals. Annual Review of Plant Physiology and Plant Molecular Biology 42:77-101.

PRADO, C.H.B.A. \& MORAES, J.A.P.V. 1996. Photosynthetic capacity and specific leaf mass in twenty woody species of cerrado vegetation under field conditions. Photosynthetica 33:103-112. 
SALISBURY, F.B. \& ROSS, C.W. 1991. Plant Physiology. Wadsworth Inc., Belmont.

SASSAKI, R.M. \& FELIPPE, G.M. 1998. Response of Dalbergia miscolobium Benth. seedlings, a cerrado tree species, to mineral nutrient supply. Revista Brasileira de Botânica 21:65-72.

SASSAKI, R.M., RONDON, J.N., ZAIDAN, L.B.P. \& FELIPPE, G.M.1999. Germination of seeds from herbaceous plants artificially stored in cerrado soil. Revista Brasileira de Biologia 59:271-279.

TERTULIANO, M.F. \& FIGUEIREDO-RIBEIRO, R.C.L. 1993. Distribution of fructose polymers in herbaceous species of Asteraceae from the cerrado. New Phytologist 123:741-749.
VAN DEN ENDE, W., DE ROOVER, J. \& VAN LAERE, A. 1999. Effect of nitrogen concentration on fructan and fructan metabolizing enzymes in young chicory plants (Cichorium intybus). Physiologia Plantarum 105:2-8.

WANG, C. \& TILBERG, J-E. 1996. Effects of nitrogen deficiency on accumulation of fructan and fructan metabolizing enzyme activities in sink and source leaves of barley (Hordeum vulgare). Physiologia Plantarum 97:339-345.

WARREN, C.R., ADAMS, M.A. \& CHEN, Z. 2000. Is photosynthesis related to concentrations of nitrogen and Rubisco in leaves of Australian native plants? Australian Journal of Plant Physiology 27:407-416. 